and the laboratories of which it consists. At what might be called the level of macroallocation, Brown will have noticed that Dr Bernadine Healy, director of NIH, has been complaining at NASA's commitment to the space station. She might as well have complained at DoE's Superconducting Super Collider, an innovative construction project with basic research attachments, which also steals funds that would be more productive in basic research. That does not imply that basic research should take precedence over all other spending on technical developments. It is rather that Brown and his colleagues should decide whether basic research incidental to the interests of operational departments of government provides the value for money they now look for from the grant-making agencies. (Amusingly, they would find that the Department of Commerce, through the National Institute of Standards and Technology, has been the engine of innovation in modern spectroscopy.)

At microallocation level, there are other questions to ask. Why is it now the general complaint of established researchers that their time is spent preparing applications for research grants? The doctrine that accountability for public money requires frequent reapplication is oldfashioned and bars the federal grant-making agencies from offering support of the kind the Howard Hughes Medical Institute has shown to be fruitful. And how correct is the common belief that the most successful applications are the safest, neither the most imaginative nor the most daring? The peer-review process, with all its virtues, tends to justify itself. And cannot the perpetual haggle about indirect costs be made at once more seemly and more equitable? NSF's experiment with grants in mathematics (see Nature 359, 94; 1992) may help even if its main purpose is different. And how is the value of extramural and intramural research to be compared? If the education of students in research counts for anything, extramural spending should have the edge.

Brown is right to assert that times are hard, and that assumptions about the funding of research must be reexamined. Many of the questions he poses are good ones, and the fact that scientists find them threatening is not proof that they should not be asked. But at a moment when the political winds - at least at NSF and NIH - appear to have actually shifted his way, it is a shame that Brown has not started down a more reasoned and realistic path. Asking research to address social and economic concerns is fair enough; asking it to provide "greater opportunities for self-realization" is not. Social science may indeed have something to contribute to the process of assessing research, but it should not dictate its ends. Although US science has repaid its country well for 45 years of investment, the time may indeed have come to rethink the contract under which it has been supported. Pity then, that Brown's vague polemic risks imflaming scientists rather than opening their minds.

\section{Trade and environment}

\section{Alarms about the risk of food contaminants may become a powerful non-tariff restraint on trade.}

WhOLESOME food and drink is everybody's wish, but what does wholesome mean? As things have turned out, most people are told by their governments what may be safely eaten or drunk. And most governments now have formal regulations defining the amounts allowed of accidental adulterants, from pesticides to radionuclides, that may be sold commercially or imported from elsewhere. The good sense of such arrangements is selfevident: government inspectors at ports are the most effective means of keeping off the world's markets animal carcasses infected with bacteria. But may not the same government inspectors restrain trade in agricultural produce that could not harm a soul, to the detriment of consumers and producers alike? That was a recurring theme at a conference in the Netherlands last week, organized by the Dutch government and the International Policy Council on Agriculture and Trade.

The issue is important because free trade in agricultural produce is the most effective way in which developing countries can work their way out of poverty. To be sure, we are a long way from the point at which that will happen. The rich countries of the world, which are ready enough to help make agriculture more efficient in developing countries, then meanly keep out the produce of the newly efficient farmers by means of tariffs and quotas. But that cannot last much longer. If Europe and the United States reach the accommodation on agriculture required for the current General Agreement on Tariffs and Trade (GATT), still in suspense, the next round of negotiations must include a deal on developing countries' farm produce.

The obvious danger is that, by then, the potential importers of foodstuffs from developing countries will have so protected themselves by finicky regulations that the imports will be deemed illegal and will be forbidden. Draconian standards on the allowable content of pesticides in foodstuffs, or insistence that imported fruit should have been grown from plants certified free from virus disease, would often be more effective than tariffs at keeping out unwelcome foodstuffs. In short, there is ample scope for unholy alliances between farm lobbies eager to protect their domestic markets and national environmental lobbies advocating the health risks associated with this or that contaminant. That is a powerful combination. The best defence against the distortion of trade that would result is an international understanding of the risks to human, animal and plant health of food contaminants. GATT, usually concerned just with numbers, should get ahead with reaching such an understanding, its other preoccupations notwithstanding.

NATURE · VOL 359 - 17 SEPTEMBER 1992 